Canadian University Music Review

Revue de musique des universités canadiennes

\title{
International Conference on Music in Eighteenth-Century Britain; The Canadian Society for Eighteenth-Century Studies / La société canadienne d'étude du dix-huitième siècle
}

\section{Paul F. Rice}

Volume 17, numéro 2, 1997

URI : https://id.erudit.org/iderudit/1014799ar

DOI : https://doi.org/10.7202/1014799ar

Aller au sommaire du numéro

Éditeur(s)

Canadian University Music Society / Société de musique des universités canadiennes

ISSN

0710-0353 (imprimé)

2291-2436 (numérique)

Découvrir la revue

Citer ce compte rendu

Rice, P. F. (1997). Compte rendu de [International Conference on Music in Eighteenth-Century Britain; The Canadian Society for Eighteenth-Century Studies / La société canadienne d'étude du dix-huitième siècle]. Canadian University Music Review / Revue de musique des universités canadiennes, 17(2), 134-136. https://doi.org/10.7202/1014799ar

All Rights Reserved (c Canadian University Music Society / Société de musique des universités canadiennes, 1997
Ce document est protégé par la loi sur le droit d'auteur. L’utilisation des services d'Érudit (y compris la reproduction) est assujettie à sa politique d'utilisation que vous pouvez consulter en ligne.

https://apropos.erudit.org/fr/usagers/politique-dutilisation/ 


\section{CONFERENCE REPORTS / COMPTES RENDUS DE COLLOQUES}

International Conference on Music in Eighteenth-Century Britain; The Canadian Society for Eighteenth-Century Studies/La société canadienne d'étude du dix-huitième siècle.

The fourth conference organized by the Centre for Eighteenth-Century Musical Studies (Cardiff University of Wales) was presented in the Department of Music from 9 to 12 July 1996, with the theme of "Music in Eighteenth-Century Britain." Sarah McCleave, who admirably organized the conference and coped with a last-minute change of venue, provided a balanced programme which featured topics relevant to church music, the oratorio, music and social context, Italian music and musicians, library collections, journals, concert music, keyboard music, and music for the theatre. Speakers came from Canada, the United States, Italy, Germany, France, and the British Isles. With some thirty presentations in all, the conference provided a remarkable opportunity not only to assess music in eighteenth-century Britain, but also the current scholarly interest in this fertile area.

The conference began with a keynote address by Peter Holman, "Eighteenth-Century English Music: Past, Present, Future." Holman, who acts as the series director for Hyperion's "The English Orpheus" recordings, spoke from his personal experience of having worked on the more than thirty-seven recordings in this series, often performing himself with the Parley of Instruments. Holman called for a revisionist history of English music, and one that would be more pro-active in overcoming traditional views about the music of native-born composers, views which appear to have been informed by a sense of cultural inferiority. Holman's more subjective comments surprised some in the audience; however, his point may well have been proven by the papers which were presented at this very conference. One might have expected that, in a conference such as this, the music of Purcell, Arne, Boyce, the Linleys, and Samuel Wesley might have figured prominently. Instead, the music of native-born composers appeared in only about one-quarter of the presentations.

Holman also took part in a concert presented by members of the Parley of Instruments, and which featured trio sonatas, theatre songs, ballads, and cantatas by Handel, Boyce, and Arne. It was clear that this group deserves the fine reputation which has developed from their recordings. Also evident was the high quality of the music that they performed. One can only hope that the major publishing project that was "brain stormed" until late one evening at the conference will eventually come to pass. Certainly, it will be difficult to 
encourage more performances of British music of this era until scores and performing parts are readily available.

Canadians taking part at the conference included: (1) Sarah McCleave (Cardiff University of Wales), "Provincial Taste and Publishing Practices: Perspectives Offered by the Mackworth Collection"; (2) James Bohun (St. John's College, Cambridge), "The Social and Political Contexts of Opera at the Accession of George II"; (3) Patricia Debly (Brock University), "Haydn's L'anima del filisofo: An Italian Opera all'inglese?"; and (4) Paul F. Rice, "Style and Influence in the Instrumental Music of John Abraham Fisher." In all, the conference proved to be a rewarding experience, and one that will hopefully encourage further research in the area of eighteenth-century British music.

The twenty-second conference of the Canadian Society for Eighteenth-Century Studies/La société canadienne d'étude du dix-huitième siècle was held at the Harbour Towers Hotel in Victoria, B.C., from 17 to 20 October 1996, under the sponsorship of the University of Victoria. The conference was presented in conjunction with the Northwestern Society for Eighteenth-Century Studies, and Carol Gibson-Wood prepared an efficiently-run and well-organized conference. Delegates attended from France, Germany, Canada, and the United States.

The theme of the conference, "Theatre of the World/Le thêâtre du monde," attracted a wide variety of topics and approaches to the study of the eighteenth century which clearly reflected the interdisciplinary nature of this society. Two plenary speakers were invited: (1) Béatrice Didier (École Normale Supérieure, Paris), "La réception de l'opéra par les philosophes"; and (2) John Barrell (University of York, U.K.), "An Entire Change of Performances?: Politics and Playbills: 1794-5." Both presentations were particularly in step with the theme of the conference, and were greatly appreciated by the conference delegates.

Music continues to figure less prominently in the meetings of this society than the undersigned would like to see. The society offers opportunities to musicians of a nature not always found in other scholarly societies. The following papers on musical topics were presented: (1) Barbara Reul (University of Victoria), "Forget Me Not: G.P. Telemann, J.F. Fasch, and the 'Minor Master' Syndrome in Germany"; (2) Ursula Rempel (University of Manitoba), "Domestic Theatricality or Theatrical Domesticity: Perceptions of Music and Performance in the Novels of Jane Austen"; (3) Anette Guse (Queen's University), "Opera on Stage and on Screen: Reflections on the Hamburg Opera (1678-1738) and Its Modern Counterpart"; (4) Alexander Sokalski (University of Saskatchewan), "Operas Based on the Chevalier de Boufflers's Reine de Golconde"; (5) David Schroeder (Dalhousie University), "Hanswurst and Carnival in Mozart's Magic Flute"; (6) Paul F. Rice (Memorial University), "John Abraham Fisher: A Career in Music in Late Eighteenth-Century London"; and (7) Mark Anderson (University of Victoria), "The Popularity and 
Criticism of English Pantomime during the 1720s." Other papers, particularly those in the area of theatre, often proved to be relevant to the study of music.

The conference delegates were further treated to the Canadian premiere of L'impresario delle canarie, two comic intermezzi with music by Domenico Sarri set to a libretto by Pietro Metastasio. These intermezzi were originally performed between the acts of Sarri's serious opera, La Didone abbandonata, in 1724. The performance, staged in the recital hall of the School of Music (University of Victoria), was sung by Meghan Atchison (soprano) and Brian Arens (baritone), accompanied by a student orchestra and all led from the harpsichord by Dr. Erich Schwandt. The text satirizes operatic conventions of the day, but is cloaked in music of great interest and melodic beauty. In addition to extended and informative programme notes written by Dr. Gordana Lazarevich, a full text and translation was given to the audience. Bravo to Drs. Lazarevich and Schwandt for providing this rare and fascinating operatic experience, also to the enthusiastic and talented student cast and orchestra!

I am pleased to announce that the twenty-third meeting of the society will be hosted by the University of Western Ontario from 16 to 19 October 1997. The conference theme will be "Le temps et ses représentations au XVIII siècle/Representations of Time in the Eighteenth Century." The conference organizer will be Dr. Thierry Belleguic.

Paul F. Rice

"Johann Friedrich Fasch und sein Wirkin für Zerbst," International Scholarly Conference on the Occasion of the Fifth International Fasch Festival, Zerbst, Germany, 18 and 19 April 1997.

Twenty scholars from Germany, Canada, the United States of America, Great Britain, Russia, and South Africa met on the occasion of the Fifth International Fasch Festival in Zerbst to present their research results on the life and works of Zerbst Court Kapellmeister Johann Friedrich Fasch (1688-1758). In contrast to two previous international conferences in 1993 and 1995 which have done little to advance our knowledge regarding Fasch's musical environment and his compositional process, ${ }^{1}$ the International Fasch Society headed by president Konstanze Musketa had lined up a number of Fasch "specialists" and paired them with experts on music of his contemporaries.

Wolfgang Ruf (Martin Luther University Halle-Wittenberg) opened the conference with the provoking "Johann Friedrich Fasch - Meister zwischen den Epochen." His thesis is that Fasch's position is determined not by the

1 The conferences which took place in 1993 and 1995 were organized by the former president and vice president of the International Fasch Society, Rüdiger Pfeiffer and Guido Bimberg, respectively. Conference proceedings were published in 1995 - Fasch und die Musik im Europa des 18. Jahrhunderts, Bericht zu den 3. Internationalen Fasch-Festtagen in Zerbst 1993, ed. Guido Bimberg and Rüdiger Pfeiffer (Köln: Böhlau, 1995) - and in 1997 - Nationalstile und Europäisches Denken in der Musik von Fasch und seinen Zeitgenossen, ed. Internationale Fasch-Gesellschaft e.V. (Dessau: Anhaitische Veriagsgesellschaft, 1997). These contain relatively few papers dealing directly with Fasch's life and works. 